\title{
BLOOM OF PERIDINIUM QUINQUECORNE ABÉ IN LA ENSENADA DE LA PAZ, GULF OF CALIFORNIA (JULY 2003)
}

\section{Ismael GÁrate-LizÁrraga ${ }^{1}$ and María del Socorro MuÑEtón-Gómez ${ }^{1,2}$}

\author{
${ }^{1}$ Instituto Politécnico Nacional, Centro Interdisciplinario de Ciencias Marinas, \\ Departamento de Plancton y Ecología Marina, Avenida Instituto Politécnico \\ Nacional s/n, Colonia Playa Palo de Santa Rita, Apdo. postal 592, 23096 La Paz, \\ Baja California Sur, México. igarate@ipn.mx \\ ${ }^{2}$ Centro de Estudios Tecnológicos del Mar núm. 4, Avenida Instituto Politécnico \\ Nacional y Calle Cetmar s/n, 23096 La Paz, Baja California Sur, México.
}

\begin{abstract}
Microalgae blooms are frequent and periodic throughout the year in La Ensenada de La Paz, a lagoon formed by a large sand bar enclosed at the southern end of the Bahía de La Paz in the southwestern Gulf of California. Brown patches of the dinoflagellate Peridinium quinquecorne Abé, an armored dinoflagellate that is cosmopolitan in neritic and estuarine waters, were observed in July 2003 near a beach at the mouth of the lagoon. The patches were about 50-100 $\mathrm{m}$ long by 10-15 $\mathrm{m}$ wide and persisted for two days when water temperature was 26.2 to $27^{\circ} \mathrm{C}$. The blooms occurred after four days of a heavy rain. Abundance of $P$.

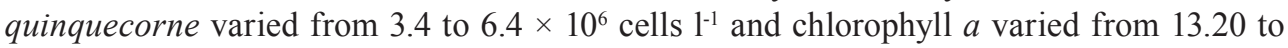
$17.75 \mathrm{mg} \mathrm{m}^{-3}$. Concentrations of nutrients in this area were higher than normal, related to a continuous re-suspension of sediment caused by wave action. The higher nutrient content promoted formation of patches of P. quinquecorne in this part of the lagoon.
\end{abstract}

Key words: Ensenada de La Paz, Gulf of California, Mexico, microalgae bloom, Peridinium quinquecorne.

\section{RESUMEN}

Los florecimientos de microalgas son frecuentes y periódicos a lo largo de todo el año en La Ensenada de La Paz, una laguna formada por una barra de arena larga que se encuentra al extremo sur de la Bahía de La Paz, ubicada al suroeste del Golfo de California. En julio de 2003 se observaron parches de color café de Peridinium quinquecorne Abé en la playa cercana a la boca de esta laguna. P. quinquecorne es un dinoflagelado tecado, el cual es cosmopolita en aguas neríticas y estuarinas. Los parches presentaron 50 y $100 \mathrm{~m}$ de largo 
por 10-15 m de ancho y fueron observados durante dos días cuando la temperatura del agua era de 26.2 a $27^{\circ} \mathrm{C}$. Los parches de $P$. quinquecorne se detectaron cuatro días después de

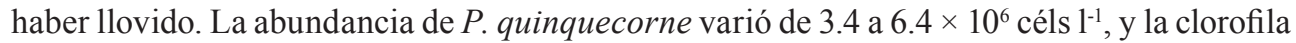
$a$ lo hizo entre 13.20 y $17.75 \mathrm{mg} \mathrm{m}^{-3}$. Las concentraciones de nutrientes en esta área fueron más altas que las normales, lo cual puede deberse a la resuspensión de sedimentos causados por acción de la marea. El alto contenido de nutrientes promovió la formación de parches de $P$. quinquecorne en esta porción de la laguna.

Palabras clave: Ensenada de La Paz, florecimiento de microalgas, Golfo de California, México, Peridinium quinquecorne.

\section{INTRODUCTION}

Microalgae blooms are proliferations of different species of phytoplankton including dinoflagellates, diatoms, raphidophytes, cyanobacteria and ciliates in coastal marine environments. Dinoflagellate blooms are often referred as red tides because of the color imparted by algae suspended in the seawater. Most species of microalgae or phytoplankton are not harmful and serve as energy producers at the base of the food web. Microalgae blooms have increased in the past 15 years in the Gulf of California (Cortés-Altamirano \& Licea-Durán, 2004; Gárate-Lizárraga et al., 2006a). Natural events, as well as human activities, have contributed to this increase; however, some of the increased notoriety, could be related to an increase of publications by Mexican researchers (Cortés-Altamirano \& Alonso-Rodríguez, 1997; Gárate-Lizárraga et al., 2001; 2004a; 2006a; Alonso-Rodríguez \& Ochoa, 2004; Cortés-Altamirano \& Licea-Durán, 2004; Band-Schmidt et al., 2005). Along the Pacific coast of Mexico, species with the greatest increase are the ciliate Myrionecta rubra (Lohman) Jankowsky and the dinoflagellate Gymnodinium catenatum Graham (Gárate-Lizárraga et al., 2006b).

The order Peridiniales includes dinoflagellates having a transverse flagellar furrow normally located within the middle third of the length of cell; the theca is composed of several tens of cellulose plates organized in several series paralleling the transverse furrow. They are free-living, photosynthetic or nonphotosynthetic dinoflagellates occurring in marine, brackish, and freshwater environments (Fensome et al., 1993). Blooms of species in this order, such as Ceratium balechii Meave, Okolodkov \& Zamudio, Ceratium furca (Ehrenberg) Claparade \& Lachman, Gonyaulax polygramma Stein, Peridinium quinquecorne Abé, Heterocapsa triquetra (Ehrenberg) Stein, and Scrippsiella trochoidea (Stein) Loeblich, (Cortés-Altamirano 
\& Alonso-Rodríguez, 1997; Gómez-Aguirre, 1998; Gárate-Lizárraga et al., 2001; 2006a; Peña-Manjarrez et al., 2005) were reported from the coasts of Mexico. Peridinium Ehrenberg is a large genus of small-to-medium-sized dinoflagellates. Some, but not all, are photosynthetic. The latter are brown because of their accessory photosynthetic pigments and occur in freshwater and marine habitats worldwide. At least a few photosynthetic species can form significant blooms, some of them associated with obnoxious odors, and fish kills. There are few reports of blooms of $P$. quinquecorne along the Pacific coast of Mexico (Cortés-Altamirano, 2002; GárateLizárraga et al., 2006a).

Bahía de La Paz is an area where blooms have been frequently sighted since 1984. More than forty blooms and twenty-five bloom-forming taxa have been recorded in this bay, including La Ensenada de La Paz (Gárate-Lizárraga et al., 2006a). The bloom-forming species belong to different phytoplankton groups: dinoflagellates, diatoms, raphidophytes, planktonic cyanobacteria, and the ciliate Myrionecta rubra. This study describes the conditions in which $P$. quinquecorne proliferated at the mouth of a lagoon in the southwestern part of the Gulf of California.

\section{MATERIAL AND METHODS}

On 23-24 July 2003, brown patches appeared in the mouth of the Ensenada de La Paz $\left(24^{\circ} 06^{\prime}-24^{\circ} 11^{\prime} \mathrm{N}, 110^{\circ} 19^{\prime}-110^{\circ} 26^{\prime} \mathrm{W}\right)$, a lagoon formed by the very large sand spit at the southern end of the Bahía de La Paz (Fig. 1). The inlet is $1.2 \mathrm{~km}$ wide, $4 \mathrm{~km}$ long and $7 \mathrm{~m}$ deep. At mean sea level, the surface area of the lagoon is approximately $45 \mathrm{~km}^{2}$. The lagoon is shallower than the inlet; with depths from 2 to $6 \mathrm{~m}$. The tide regimen is a mixed semidiurnal type (Obeso-Niebla et al., 1993).

Sea surface temperature was measured with a bucket thermometer (Kahlsico International Corp., El Cajon, CA, USA). Water samples were collected in plastic bottles to determine nutrient concentrations $\left(\mathrm{NH}_{4}, \mathrm{NO}_{3}, \mathrm{PO}_{4}\right.$, and $\left.\mathrm{SiO}_{4}\right)$, pigments, and identification and abundance of species of phytoplankton. Samples of phytoplankton from the bloom areas were fixed and preserved with Lugol's solution for identification and cell counts. We estimated abundance of phytoplankton at the same time as we identified the microorganisms. Cell counts were made in 5-ml settling chambers under an inverted phase contrast microscope (Hasle, 1978). Photographic documentation of the main representative dinoflagellate species was made with a digital camera (Cool SNAP-Pro Media Cybernetics, Silver Spring, MD, USA) and imaging software (Image-Pro Plus 4.1, Media Cybernetics). 


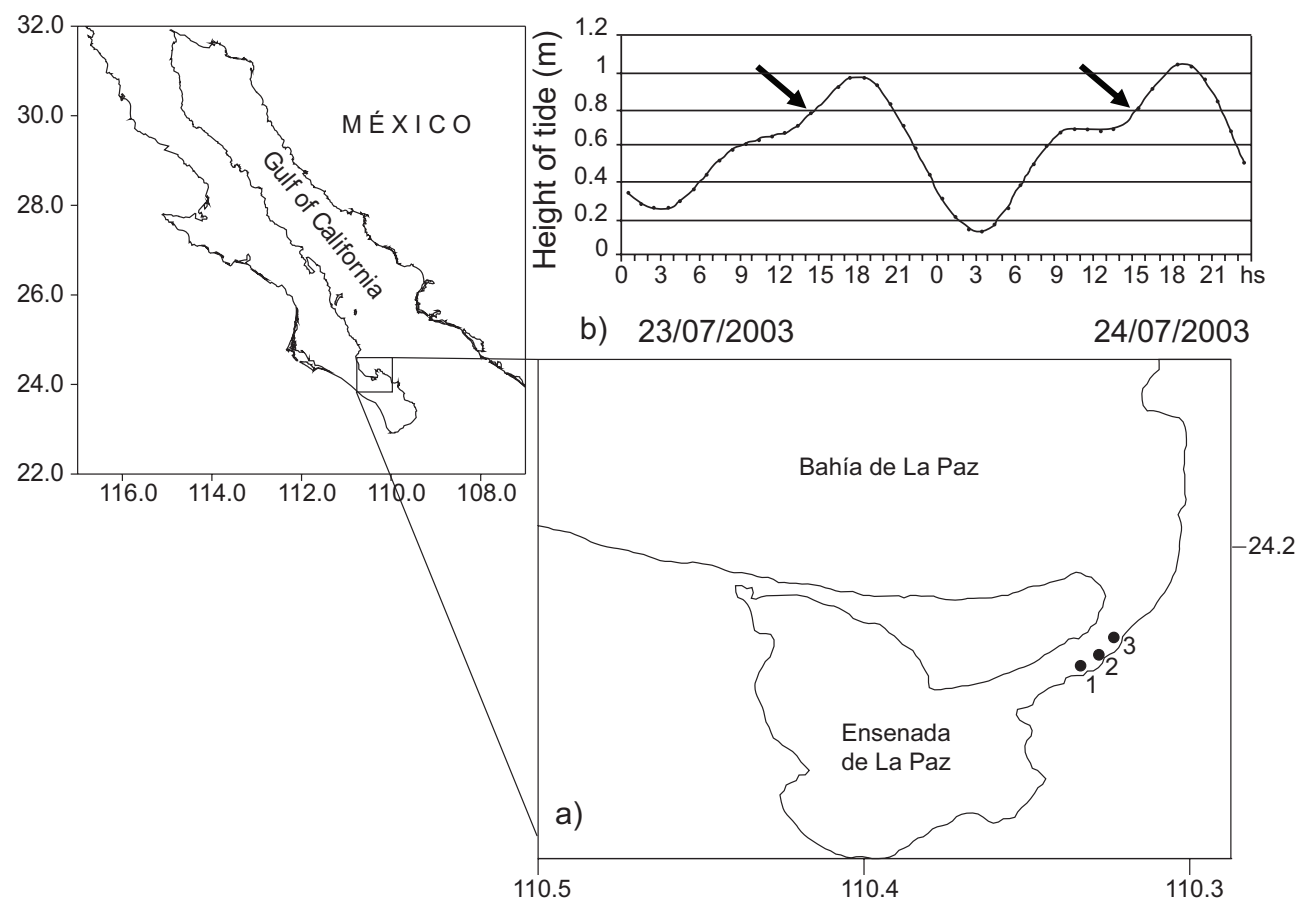

Fig. 1. a) Location of blooms dominated by Peridinium quinquecorne; b) tidal variations on 23 and 24 July 2003. Arrows indicate the time of sampling.

To quantify phytoplankton biomass $250-\mathrm{ml}$ seawater was passed through Whatman GF/F filters and the filters were frozen at $-20{ }^{\circ} \mathrm{C}$ until further analysis. Filters were thawed and extracted in $10 \mathrm{ml}$ of $90 \%$ acetone overnight at $4{ }^{\circ} \mathrm{C}$ in the dark. Chlorophyll $a$ concentrations were calculated from spectrophotometric absorbance measurements using the equations of Jeffrey \& Humprey (1975). Nutrients were measured according to Strickland \& Parson (1972). Tidal records were obtained from a meteorological station located $200 \mathrm{~m}$ from the southwestern shore of the Ensenada de La Paz.

\section{RESULTS}

Brownish patches ( $\sim 50-100 \mathrm{~m}$ long, $10-15 \mathrm{~m}$ wide) were directly observed for two days in the mouth of the lagoon during rising tides (Fig. 1b). Surface water 
temperature in the bloom ranged from 26.2 to $27.0^{\circ} \mathrm{C}$. The patches were observed for two days after four days of rain. Concentrations of nutrients (in $\mu \mathrm{M}$ ) were higher during the first day and varied as follows: ammonium (1.01 to 3.56), nitrites (0.26 to $1.86)$, nitrates ( 0.31 to 3.59$)$, orthophosphates ( 0.65 to 1.42$)$, and silicates (2.13-10.21) (Figs. 2a, 2b).

The phytoplankton samples were mainly dominated by $P$. quinquecorne ( $>99 \%$ of the total phytoplankton abundance). A total of 26 microalgae species were identified. Dinoflagellates were by far the most important group in abundance (9 species), but diatoms were more diverse (17 species) (Table 1). The density of phytoplankton at the sampling stations was similar on both days, varying from 3.823 to $6.208 \times 10^{6}$ cells $1^{-1}$ on day 1 and 3.408 to $6.429 \times 10^{6}$ cells $1^{-1}$ on day 2 (Fig. 2c; Table 1). Of this biomass, P. quinquecorne ranged from 3.8 to $6.2 \times 10^{6}$ cells $1^{-1}$ on day 1 and 3.4 to $6.4 \times 10^{6}$ cells $1^{-1}$. Phytoplankton chlorophyll $a$ varied from 15.84 to $16.91 \mathrm{mg} \mathrm{m}^{-3}$ on day 1 and 13.20 to $17.75 \mathrm{mg} \mathrm{m}^{-3}$ on day 2 (Fig. 2c). Peridinium quinquecorne cells varied greatly in size. Cells were 20 to $32 \mu \mathrm{m}$ long (25 to $36 \mu \mathrm{m}$ with spines) and 16 to $18 \mu \mathrm{m}$ wide. P. quinquecorne cells have a pointed apex, and a number of projections from the hypocone (Fig. 3a, b, c, d). The girdle is comparatively wide and located at the middle of the cells. Chromatophores are numerous, ovoidal and brownish green. The pulsing vacuole that connects to the flagellar pore of the transversal flagellum is reddish and looks like an eyespot. Among diatoms, Odontella aurita (Lyngbye) Brebison and Nitzschia sigma (Kützing) Smith were the most abundant species. Blooms of Nitzschia sigma (2.8 to $3.4 \times 10^{6}$ cells $1^{-1}$ ) occurred in September 1999 in shrimp ponds bordering Bahia de La Paz (unpublished data).

\section{DISCUSSION}

Peridinium quinquecorne is an armored dinoflagellate, characterized by four prominent antapical spines and a more-or-less angular shape (Abé, 1981). Balech (1974) transferred the species to the genus Protoperidinium, making the new combination Protoperidinium quinquecorne (Abé) Balech. Since this organism has 3 apical plates, 2 anterior intercalary plates, 7 precingular plates, 5 cingular plates, 5 postcingular plates, and 2 anteapical plates, we agree with Fukuyo et al. (1990) that it is not appropriate to place this species in the genus Protoperidinium, because this genus is characterized by possessing four cingular plates, including a transitional plate (Horiguchi \& Pienaar, 1991). However, taxonomically its generic position is 

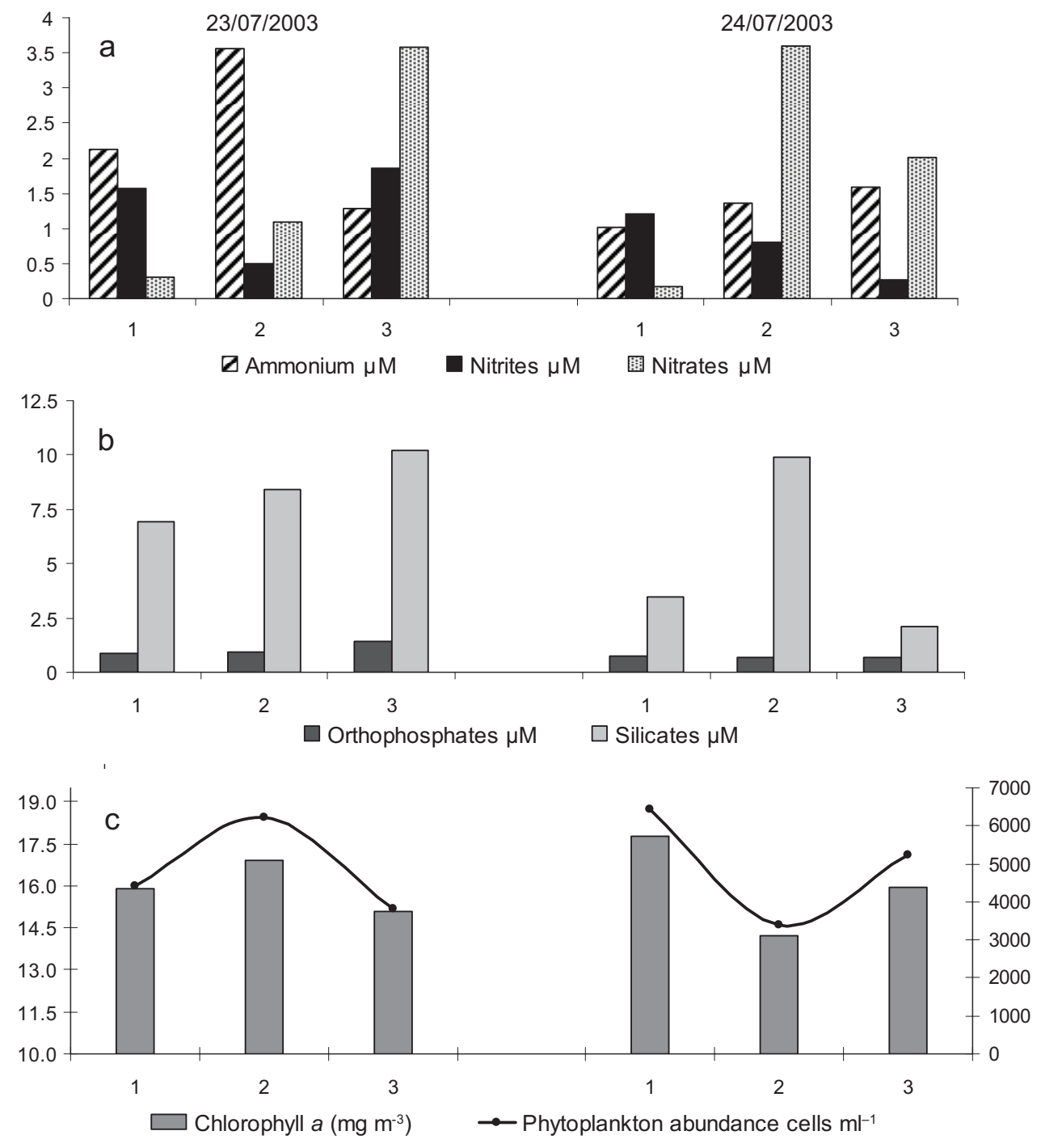

Fig. 2. Variations in variables at three sampling sites on two consecutive days. a. Ammonium, nitrites, nitrates; b. orthophosphates, and silicates are in $\mu \mathrm{M}$; c. chlorophyll $a$ is in $\mathrm{mg} \mathrm{m}^{-3}$ and total phytoplankton abundance is in cells $\mathrm{ml}^{-1}$.

still controversial, with the further possibility that this species may belong to the genus Pentapharsodinium (Steidinger \& Tangen, 1997). Peridinium quinquecorne has a wide geographical distribution, ocurring along the coasts of Belize, Brazil, 
Gárate-Lizárraga y Muñetón-Gómez: Bloom of Peridinium quinquecorne in Gulf of California

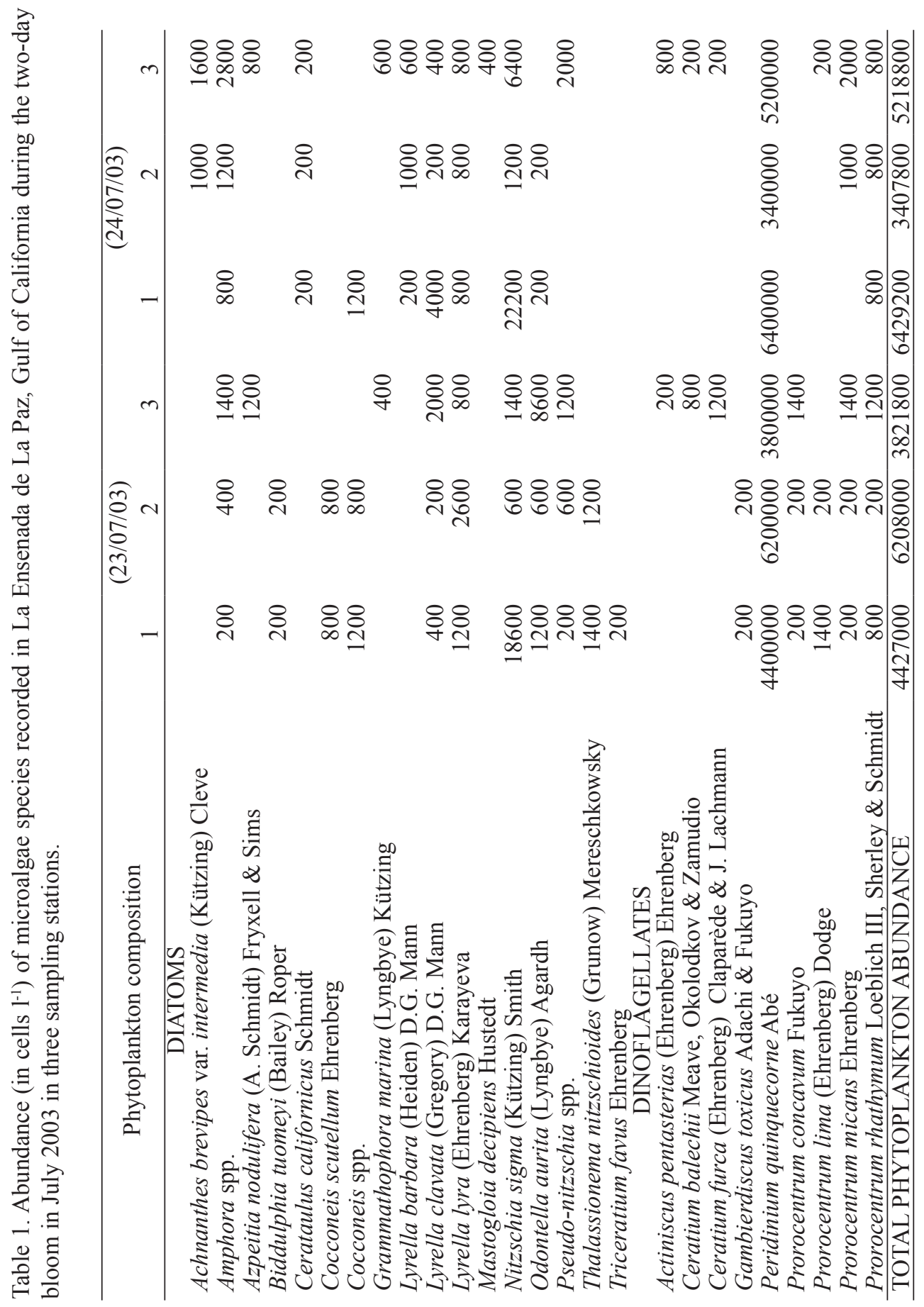




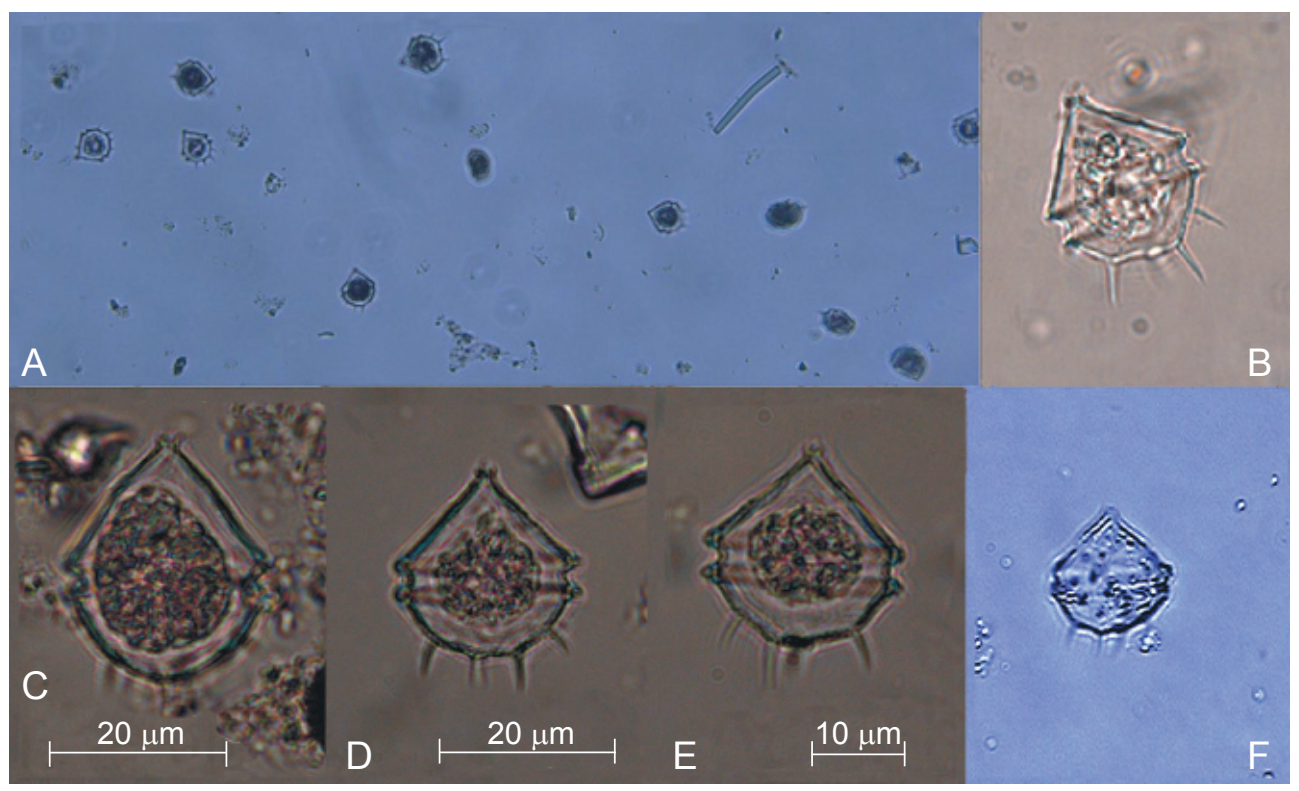

Fig. 3. Peridinium quinquecorne cells observed under light microscopy: A. water sample with several specimens; B, C, D, E and F. photographs of individual specimens.

China, India, Malaysia, Mexico, Japan, Russia, South Africa, Spain, Tunisia, and the USA (Abé, 1981; Dodge, 1985; Konovalova et al., 1989; Horiguchi \& Pienaar, 1991; Shamsudin et al., 1996; Tomas, 1998: Trigueros \& Orive 2000; Turki \& El Abed, 2001; Faust et al., 2005; Barón-Campis et al., 2005; Gárate-Lizárraga et al., 2006a; Proença et al., 2006, Okolodkov et al., 2007).

Along the Pacific coast of Mexico, P. quinquecorne is distributed from Punta Baja, Baja California (295' N, $\left.115^{\circ} 49^{\prime} \mathrm{W}\right)$ to around Puerto Madero, Chiapas (14 $41^{\prime} \mathrm{N}$ and $92^{\circ} 25^{\prime} \mathrm{W}$ ) (Okolodkov \& Gárate-Lizárraga, 2006; Gárate-Lizárraga et al., 2007a; this study) (Fig. 4). In the Gulf of California, Martínez-López \& GárateLizárraga (1994) first reported this species in Bahía Concepción. Recently, this species has been observed in Bahía de Los Angeles on the northwestern coast of the Gulf of California (Gárate-Lizárraga, this study) and in several coastal lagoons of the Sinaloa state in low concentrations (Ibarguen-Zamudio, 2006). Cortés-Altamirano et al. (2006) described $P$. quinquecorne as a recent introduction species in the Gulf of California, but this hypothesis is not well supported because dinoflagellates are a difficult group to identify. According to Alonso-Rodríguez \& Ochoa (2004) the first observation of this species was incorrectly identified as Amylax triacantha 


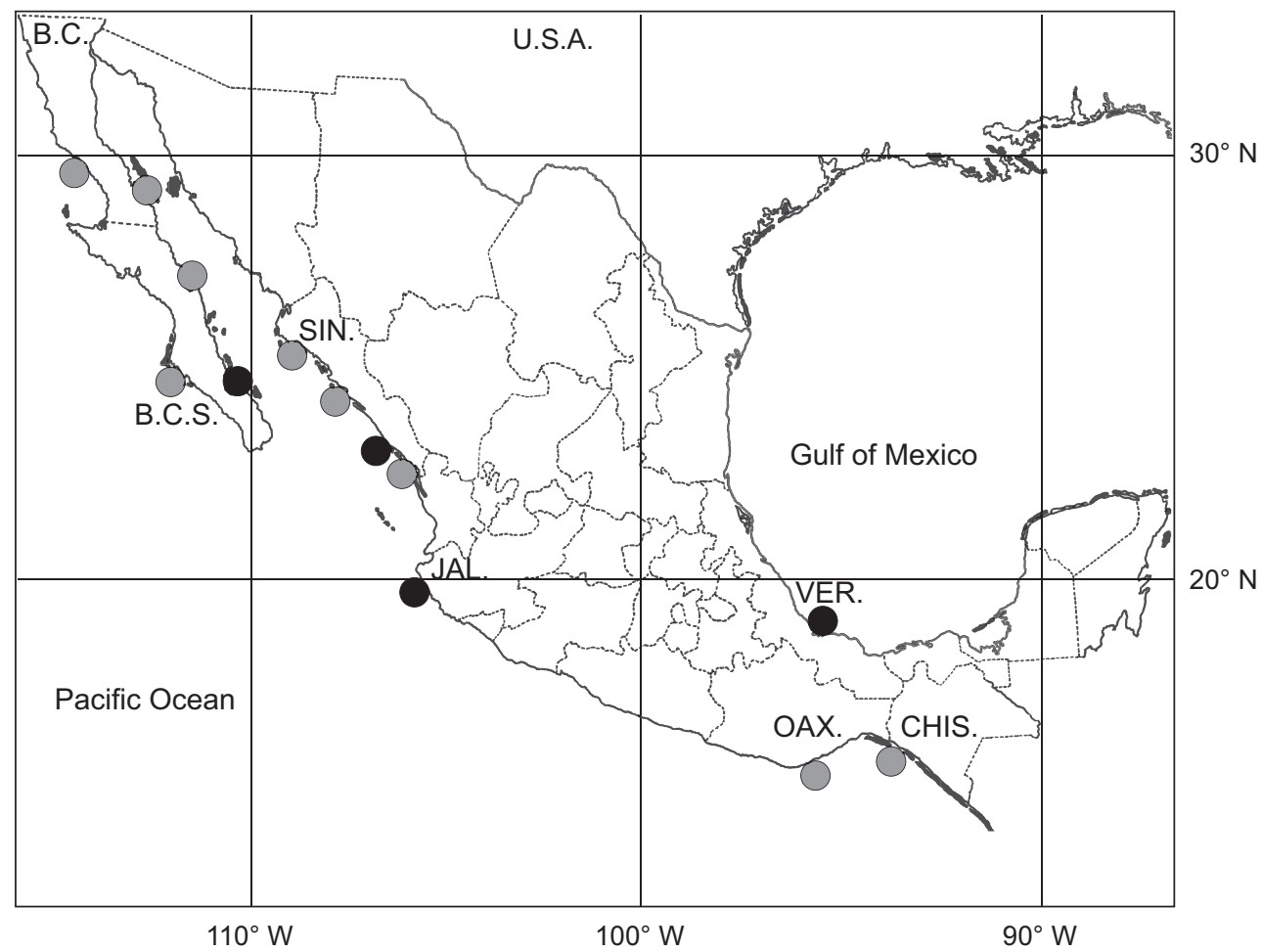

Fig. 4. Reports (gray circles) and blooms (black circles) of Peridinium quinquecorne along both coasts of Mexico. Sources: Martínez-López \& Gárate-Lizárraga (1994), CortésAltamirano \& Licea-Durán (2004), Barón-Campis et al. (2005), Anonymous (2005), GárateLizárraga et al. (2006a,b), Okolodkov \& Gárate-Lizárraga (2006), Ibarguen-Zamudio (2006), Okolodkov et al. (2007), this study. B.C. = Baja California, B.C.S. = Baja California Sur, CHIS. $=$ Chiapas, $\mathrm{JAL}=$ Jalisco, $\mathrm{SIN} .=$ Sinaloa, $\mathrm{OAX} .=$ Oaxaca and VER.$=$ Veracruz.

(Jørgensen) Sournia. It is possible that the small cells of $P$. quinquecorne (20 to 32 $\mu \mathrm{m})$ have been present in Mexican waters much earlier, but in low concentrations (Martínez-López \& Gárate-Lizárraga, 1994) and not identified correctly or simply ignored.

Concentrations of nutrients were higher than reported for the inlet part of the lagoon in a previous study (Cervantes-Duarte et al., 2001). This may be a consequence of collecting samples near the beach (at 1-3 m deep), where bottom sediments are agitated by wave action. Brownish patches of $P$. quinquecorne were directly observed when tide was rising, suggesting that the bloom observed near the 
shore is in part a result of an accumulation processes. Faust et al. (2005) identified P. quinquecorne in floating detritus at Douglas Cay and The Lair in Belize also forming red tides too $\left(1.15 \times 10^{4}\right.$ cells $\left.1^{-1}\right)$. Okolodkov et al. (2007) found P. quinquecorne in some samples of macrophytes in a reef zone near Veracruz, Mexico. They postulated that this species is part of epiphytic assemblages and could be the organism involved in recurrent red tides observed in 2005 on 24 May, 4 and 12, August, 12 to 14, 18 and 25 October, and in 2006 on 20 June, 25 July to 5 August, and 15 August. Blooms of $P$. quinquecorne in Veracruz always occurred very close to the coastline. We suggest that blooms near the beach indicate that this species prefers nutrient-rich environments. Shamsudin et al. (1996) reported a $P$. quinquecorne bloom in brackish fishponds at Terengganu, Malaysia on the South China Sea, where organic and inorganic nutrients were high during the dry season prior to the wet monsoon. They concluded that this seasonal condition favored proliferation of P. quinquecorne. Horstmann (1980) states that P. quinquecorne forms blooms in eutrophic and polluted brackish environments, tolerating temperatures up to $30^{\circ} \mathrm{C}$. However, blooms tend to disappear when temperatures drop sharply. It appears to tolerate salinity from 31 to 38 ups. According to the available information we can draw the conclusion that $P$. quinquecorne is well-adapted to benthic and planktonic shallow-subtropical embayments.

Gárate-Lizárraga et al. (2006a) reported small, isolated blooms of $P$. quinquecorne in May $2003\left(2.1 \times 10^{6}\right.$ cells $\left.{ }^{1-1}\right)$ and July $2004\left(2.97 \times 10^{6}\right.$ cells $\left.{ }^{1-1}\right)$ in Bahía de La Paz and suggested that these densities are typical occurrences. In contrast, Proença et al. (2006) reported $45 \times 10^{6}$ cells $1^{-1}$ and pigment biomass of $356.2 \mathrm{mg} \mathrm{m}^{-3}$ during a bloom of $P$. quinquecorne at Balneário Camboriú, Santa Catarina, Brazil. In our investigation, chlorophyll $a$ varied from 15.84 to $16.91 \mathrm{mg} \mathrm{m}^{-3}$ on day 1 and 13.20 to $17.75 \mathrm{mg} \mathrm{m}^{-3}$ on day 2 , which was similar to other events in this area involving diatoms, other dinoflagellates, and ciliates (Gárate-Lizárraga, et al., 2003; 2004a, 2006a). De Madariaga et al. (1989) found that P. quinquecorne was responsible for most of the primary production in the Gernika Estuary (Guernica, Urdaibai) during the blooms of the summer 1987.

Cervantes-Duarte et al. (2001) reported seasonal variations in chlorophyll $a$ for La Ensenada de La Paz ranging from 1.25 to $2.19 \mathrm{mg} \mathrm{m}^{-3}$. This is an eight-fold increase in phytoplankton biomass during the P. quinquecorne bloom here reported Blooms are also responsible for maintaining marine fertility in this lagoon (GárateLizárraga et al., 2004a; López-Cortés et al., 2006). Blooms of other phytoplankton species occur in the Bahía de La Paz, where particular seasonal conditions have been determined to lead to proliferation of some species (Gárate-Lizárraga et al., 
2001, 2006a, 2007b). Cortés-Altamirano (2002) was the first to report a bloom of $P$. quinquecorne in the Bahía de Mazatlán in Sinaloa, at the end of August 1990 (rainy season) however, cells counts were not made. In our study area, the first blooms of P. quinquecorne were observed in May 2003, the first week in July 2004 and the two days described in this study. Runoff seems to be a contributing factor to blooms of P. quinquecorne, occurring four days after a heavy rain event. De Madariaga et al. (1989) mentioned that the start of a P. quinquecorne bloom took place during neap tides after a period of rain that provided the estuary with a considerable amount of nutrients, mainly nitrogen compounds and silicate. This pattern supports the view that $P$. quinquecorne requires particular environmental conditions to develop into a dense bloom.

Blooms in Bahía de La Paz between May and July are very common (GárateLizárraga et al., 2006a; 2007b). López-Cortés et al. (2006) suggested that steady winds from the south re-suspend sediments from the shallow bottoms of the euphotic zone by creating upwelling of nutrient-rich waters. This promotes massive increases of phytoplankton and formation of single species blooms. No harmful effects were observed during the bloom of $P$. quinquecorne we report here. Yan et al. (2002) estimated fish kills and economical losses from a $20-\mathrm{km}$ long bloom caused by Scrippsiella trochoidea and P. quinquecorne in Daya Bay, Guangdong, China. Additionally, blooms of $P$. quinquecorne can be associated with low dissolved oxygen levels in the water. Low concentrations usually occur in water bodies between 4 and $8 \mathrm{a} . \mathrm{m}$. and can cause fish kills in confined areas because there is no oxygen left for the fish to use (http://research.myfwc.com/features/view_article.asp?id=24273).

Monitoring programs in Bahía de La Paz provide monthly and seasonal data of bloom species, as well as environmental conditions near the bloom sites (GárateLizárraga et al., 2003; 2004b; 2006a; 2007b). This monitoring program has allowed us to identify new blooming species such as Gyrodinium instriatum Freudenthal et Lee, Akashiwo sanguinea (Hirasaka) G. Hansen \& Moestrup, Octactis pulchra Schiller, Thalassiosira sp. and the toxic diatom species Pseudonitzschia fraudulenta (P.T. Cleve) Hasle, P. pungens (Grunow ex P.T. Cleve) Hasle, and P. pseudodelicatissima (P.T. Cleve) Heiden (Gárate-Lizárraga et al., 2006a; 2007b.) Seasonal variations of toxic species, such as Gymnodinium catenatum and the degree of toxicity have already been determined (Gárate-Lizárraga et al., 2004b; 2005) for blooms in this bay. Given the frequent occurrence of blooms, some of which are toxic, monitoring programs must be intensified. Acquiring more data on seasonal variations, duration of blooms, ecological succession of phytoplankton species, will improve our ability to understand the possible impact on human health. Alternative methods, including 
satellite images must be improved to detect microalgae blooms between one sampling and another. Additional areas must be studied, particularly areas where mollusks represent an important commercial fishery.

\section{ACKNOWLEDGEMENTS}

The Instituto Politécnico Nacional (projects SIP-200603327; SIP-20071252) financed this study. The first author received a fellowship from the Comisión de Cooperación y Fomento de Actividades Académicas (COFAA) and from Estímulos al Desempeño de los Investigadores (EDI). Thanks to María Clara Ramírez-Jáuregui (Instituto de Ciencias del Mar y Limnología, Universidad Nacional Autónoma de México), for the literature search. The group of benthic diatoms from Centro Interdisciplinario de Ciencias Marinas del Instituto Politécnico Nacional confirmed identification of some diatom species. Thanks to Guillermo Gutiérrez de Velasco (Centro de Investigación Científica y de Educación Superior de Ensenada, Unidad La Paz) for tide data. We wish to dedicate this paper to the memory of Samuel Gómez-Aguirre (1937-2006) who made some important contributions to the study of dinoflagellate blooms in Mexico.

\section{LITERATURE CITED}

Abé, T. H. 1981. Studies on the family Peridinidae: an unfinished monograph of the armored dinoflagellata. Spec. Pub. Seto Mar. Biol. Lab. 6: 1-409.

Alonso-Rodríguez, R. \& J. L. Ochoa. 2004. Hydrology of winter-spring "red-tides" in Bahía de Mazatlán, Sinaloa, Mexico. Harmful Algae 3: 163-171.

Anonymous. 2005. Seventh session of the IOC Intergovernmental Panel on Harmful Algal Blooms. Intergovernmental Oceanographic Commision (of UNESCO). UNESCO Headquarters, Paris, 16-18 March 2005. http://unesdoc.unesco.org/images/0013/ 001394/139451e.pdf

Balech, E. 1974. El género Protoperidinium Bergh, 1881 (Peridinium Ehrenberg, 1831, partim). Rev. Mus. Arg. Cienc. Nat. "B. Rivadavia" Hidrobiol. 4: 1-78.

Band-Schmidt, C., A. Martínez-López \& I. Gárate-Lizárraga. 2005. First record of Chattonella marina in Bahía de la Paz, Gulf of California. Harmful Algae News. An IOC Newsletter on toxic algae and algal blooms 28: 6-7.

Barón-Campis, S. A., D. U. Hernández-Becerril, N. O. Juárez-Ruíz \& C. Ramírez-Camarena. 2005. Marea roja producida por el dinoflagelado Peridinium quinquecorne en Veracruz, México (Oct.-Nov. 2002): morfología del agente causal. Hidrobiológica 15: 73-78. 
Cervantes-Duarte, R., F. Aguirre-Baena, A. Reyes-Salinas \& J. E. Valdez-Holguín. 2001. Caracterización hidrológica de una laguna costera de Baja California Sur, México. Oceánides 16: 1-11.

Cortés-Altamirano, R. 2002. Mareas rojas: biodiversidad de microbios que pintan el mar. In: Cifuentes, J. L. \& J. Gaxiola-López (eds.). Atlas de biodiversidad de Sinaloa. Colegio de Sinaloa. Guadalajara, Jalisco. pp. 29-41.

Cortés-Altamirano, R. \& R. Alonso-Rodríguez. 1997. Mareas rojas durante 1997 en la Bahía de Mazatlán, Sinaloa, México. Rev. Cienc. del Mar, UAS 15: 31-37.

Cortés-Altamirano, R. \& S. Licea-Durán. 2004. Decoloración de proliferaciones de microalgas como parámetro bioindicador en la Bahía de Mazatlán, México. Rev. Biol. Trop. 52(Suppl. 1): 27-34.

Cortés-Altamirano, R., M. F. Lavín, A. Sierra-Beltrán \& M. C. Cortés-Lara. 2006. Hypothesis about transport of invader microalgae from East to the Gulf of California by marine currents. Rev. Cienc. del Mar, UAS 18: 19-26.

de Madariaga, I., E. Orive \& G. T. Boalch. 1989. Primary production in the Gernika Estuary during a summer bloom of a dinoflagellate Peridinium quinquecorne Abé. Bot. Mar. 32: $159-165$.

Dodge, J. D. 1985. Marine dinoflagellates of the British Isles. HM Stat. Office, London. 303 $\mathrm{pp}$.

Faust, M. A., R. W. Litaker, M. W. Vandersea, S. R. Kibler \& P. A. Tester. 2005. Dinoflagellate diversity and abundance in two Belizean coral reef-mangrove lagoons: A test of Margalef's Mandala. Atoll Res. Bull. 534: 105-131.

Fensome, R. A., F. J. R. Taylor, G. Norris, W. A. S. Sarjeant, D. I. Wharton \& G. L. Williams. 1993. A classification of living and fossil dinoflagellates. Micropaleontology Special Publication Number 7. 351 pp.

Fukuyo, Y., H. Takano, M. Chihara \& K. Matsuoka. 1990. Red tide organisms in Japan. An illustrated taxonomic guide. Uchida Rokakuho. Tokyo. 407 pp.

Gárate-Lizárraga, I., M. L. Hernández-Orozco, C. J. Band-Schmidt \& G. Serrano-Casillas. 2001. Red tides along the coasts of the Baja California Sur, Mexico (1984 to 2001). Oceánides 16: 127-134.

Gárate-Lizárraga, I., D. A. Siqueiros-Beltrones \& V. Maldonado-López. 2003. First record of a Rhizosolenia debyana bloom in the Gulf of California, Mexico. Pac. Sci. 57(2): 141-145.

Gárate-Lizárraga, I., D. J. López-Cortés, J. J. Bustillos-Guzmán \& F. E. HernándezSandoval. 2004a. Blooms of Cochlodinium polykrikoides (Gymnodiniaceae) in the Gulf of California, Mexico. Rev. Biol. Trop. 52(Suppl. 1): 51-58.

Gárate-Lizárraga, I., J. J. Bustillos-Guzmán, K. Erler, M. S. Muñetón-Gómez, B. Luckas \& A. Tripp-Quezada. 2004b. Paralytic shellfish toxins in the chocolata clam, Megapitaria squalida (Bivalvia: Veneridae), in Bahía de La Paz, Gulf of California. Rev. Biol. Trop. 52(Suppl. 1): 133-140.

Gárate-Lizárraga, I., J. J. Bustillos-Guzmán, M. L. Morquecho-Escamilla, C. J. BandSchmidt, R. Alonso-Rodriguez, K. Erler, B. Luckas, A. Reyes-Salinas \& D. T. Góngora-González. 2005. Comparative paralytic shellfish toxin profiles in the strains of Gymnodinium catenatum Graham from the Gulf of California, Mexico. Mar. Poll. Bull. 50: 208-236. 
Gárate-Lizárraga, I., M. S. Muñetón-Gómez \& V. Maldonado-López. 2006a. Florecimiento del dinoflagelado Gonyaulax polygramma frente a la Isla Espíritu Santo, Golfo de California (Octubre 2004). Rev. Invest. Mar. 17: 31-39.

Gárate-Lizárraga, I., C. J. Band-Schmidt, D. J. López-Cortés, J. J. Bustillos-Guzmán \& M. S. Muñetón-Gómez. 2006b. Harmful algal blooms along the Mexican Pacific coast (1878-2006). VII Reunión Internacional de Planctología, del 30 de Mayo al 3 de Junio del 2006, Morelia, Michoacán (Book of Abstracts).

Gárate-Lizárraga, I., C. J. Band-Schmidt, G. Verdugo-Díaz, M. S. Muñetón-Gómez \& E. F. Félix-Pico. 2007a. Dinoflagelados (Dinophyceae) del sistema lagunar MagdalenaAlmejas. In: Funes-Rodríguez, R., J. Gómez-Gutiérrez, R. Palomares-García (eds.). Estudios ecológicos en Bahía Magdalena. Centro Interdisciplinario de Ciencias Marinas-Instituto Politécnico Nacional. La Paz, Baja California Sur, México. pp. 145-174.

Gárate-Lizárraga, I., C. J. Band-Schmidt, J. J. Bustillos-Guzmán \& D. J. López-Cortés. 2007b. Bloom of Pseudo-nitzschia fraudulenta in Bahía de La Paz, Gulf of California (June-July 2006). Harmful Algae News, an IOC Newsletter on toxic algae and algal blooms. Paris. 32: 6-7.

Gómez-Aguirre, S. 1998. Red tide occurrences recorded in Mexico from 1980 to 1992. An. Inst. Biol. UNAM, Ser. Zool. 69(1): 13-22.

Hasle, G. R. 1978. Using the inverted microscope. In: Sournia, A. (ed.). Phytoplankton manual. UNESCO. Paris. pp. 191-196.

Horiguchi, T. \& R. N. Pienaar. 1991. Ultrastructure of a marine dinoflagellate, Peridinium quinquecorne Abé (Peridiniales) from South Africa with particular reference to its chrysophyte endosymbiont. Bot. Mar. 34: 123-131.

Horstmann, U. 1980. Observations on the peculiar diurnal migration of a red tide Dinophyceae in tropical shallow waters. J. Phycol. 16: 481-485.

Ibarguen-Zamudio, J. 2006. Composición, variación y abundancia de las comunidades fitoplanctónicas en tres lagunas costeras del estado de Sinaloa, México, periodo 20042005. Tesis de licenciatura. Facultad de Ciencias del Mar, Universidad Autónoma de Sinaloa. Mazatlán. Sinaloa. 105 pp.

Jeffrey, S. W. \& G. F. Humphrey. 1975. New spectrophotometric equations for determining chlorophylls $a, b, c_{1}$ and $c_{2}$ in higher plants, algae and natural phytoplankton. Biochem. Physiol. Pflanz 167: 191-194.

Konovalova, G. V., T. Y. Orlova \& L. A. Pautova. 1989. Atlas of the phytoplankton of the Japan Sea. Nauka, Leningrad, 185 pp.

López-Cortés, D. J., J. J. Bustillos-Guzmán \& I. Gárate-Lizárraga. 2006. Unusual mortality of krill in Bahía de La Paz, Gulf of California. Pac. Sci. 60(2): 235-242.

Martínez-López, A. \& I. Gárate-Lizárraga. 1994. Quantity and quality of the particulate organic matter in Concepcion Bay during the spawning season of the scallop Argopecten circularis (Sowerby, 1835). Cien. Mar. 20: 301-320.

Obeso-Niebla, M., A. Jiménez-Illescas \& S. Troyo-Diéguez. 1993. Modelación hidrodinámica de la marea en la ensenada de La Paz. Invest. Mar. 4: 241-256. 
Okolodkov, Y. B. \& I. Gárate-Lizárraga. 2006. An annotated checklist of dinoflagellates (Dinophyceae) from the Mexican Pacific. Acta Bot. Mex. 74: 1-154.

Okolodkov, Y. B., G. Campos-Bautista, I. Gárate-Lizárraga, J. A. G. González-González, M. Hoppenrath \& V. Arenas. 2007. Seasonal changes of benthic and epiphytic dinoflagellates in the Veracruz reef zone, Gulf of Mexico. Aquat. Microb. Ecol. 47(3): 223-237.

Peña-Manjarrez, J. L., J. Helenes-Escamilla, G. Gaxiola-Castro \& E. Orellana-Cepeda. 2005. Dinoflagellate cysts and bloom events at Todos Santos Bay, Baja California, México, 1999-2000. Cont. Shelf Res. 25: 1375-1393.

Proença, L. A., C. Odebrecht, L. L. Mafra-Junior \& M. S. Tamanaha. 2006. Floração de Peridinium quinquecorne Abé na Enseada de Balneario Camburiú, S.C. Simposio Latino-americano sobre Algas Nocivas, 2006. Book of Abstracts. Itajai, Santa Catarina, Brasil. 244 pp.

Shamsudin, L., A. Awang, A. Ambak \& S. Ibrahim. 1996. Dinoflagellate bloom in tropical fish ponds of coastal waters of the South China Sea. Environ. Monitor. Assess. 40(3): 303-311.

Steidinger, K. \& K. Tangen. 1997. Dinoflagellates. In: Tomas, C. R. (ed.). Identifying marine phytoplankton. Academic Press, Inc. San Diego, California. pp. 387-589.

Strickland, J. D. H. \& T. R. Parson. 1972. A practical handbook of seawater analysis. 2nd ed. Fisheries Research Board of Canada. Ottawa. 167. 310 pp.

Tomas, C. 1998. Blooms of potentially harmful raphidophycean flagellates in Florida coastal waters. In: Reguera, B., J. Blanco, M. L. Fernández \& T. Wyatt (eds.). Harmful Algae. Xunta de Galicia and IOC-UNESCO. Santiago de Compostela. pp. 101-103.

Trigueros, J. M. \& E. Orive. 2000. Tidally driven distribution of phytoplankton blooms in a shallow, macrotidal estuary. J. Plankton Res. 22: 969-986.

Turki, S. \& A. El Abed. 2001. On the presence of potentially toxic algae in the lagoons of Tunisia. Harmful Algae News. An IOC Newsletter on toxic algae and algal blooms 22: 10 .

Yan, T., Z. Ming-Jiang \& Z. Jing-Zhong. 2002. A national report on harmful algal blooms in China. In: Taylor "Max", F. J. R. \& V. L. Trainer (eds.). Harmful algal blooms in the PICES region of the North Pacific. PICES Scientific Report No. 23. North Pacific Marine Science Organization, Sidney, BC, Canada. pp. 119-128. 